\title{
Possible Impacts of Wastewater Discharge from the University of Calabar Teaching Hospital on the Biota of Great Kwa River, Nigeria
}

\author{
Ama-Abasi DE*, William G and Akpan ER \\ Institute of Oceanography, University of Calabar, Nigeria
}

Submission: February 19, 2017; Published: March 24, 2017

*Corresponding author: Ama-Abasi DE, Institute of Oceanography, University of Calabar, Nigeria, Email: amaabasi2@yahoo.com

\section{Introduction}

Waste water generated from hospitals usually contain pathogens human tissues and fluids partially metabolized pharmaceutical substances with genotoxic properties, chemical substances, heavy metals, and radioactive waste, which may endanger public health and welfare. According to Emmanuel et al. [1], hospitals generate an average of 750 litres of waste water by bed per day. These effluents are loaded with pathogenic microorganisms and other toxic chemical substances Hospital effluent and most public waste water eventually end up in streams, lakes, rivers, sea, ocean where they often have deleterious effects on the receiving environment and interfere with the legitimate uses of the water resources Eg. Water for drinking, recreation, agriculture, aquaculture, industrial purposes and transportation among others. These hazardous effects are more pronounced and felt in communities where waste water treatment is lacking or inadequate [2,3].

The negative effect of chemicals on organisms is mainly due to their toxicity. The toxicity depends upon the species and environments concerned as well as the properties of the chemical involved (such as the combination of several pollutants and physic-chemical condition of the water). Water pollution results in outright perturbation of the ecosystem including total destruction of the ecosystem shifts in ecosystem balance and alteration of the ecological processes. All of these effects harm the ecosystems and can significantly impede ecosystem services that are important to us such as providing potable water, preserving fisheries, protection from floods.

The University of Calabar Teaching Hospital is located at the West Bank of the Great Kwa River. It is an ultra-modern Institution with, state of the arts facilities including functional departments like In- patients, Consultant Out- Patient, General Out-patient department, Accident and Emergency department, delivery/ antenatal department, surgical wards, various laboratories attached to different units including microbiology/ parasitology laboratories, pathology, histology, and radiology and radiography laboratories. Being a tertiary health institution, for tertiary health care delivery, the Hospital is endowed with state of the art research laboratories. Waste water from the Teaching Hospital drains via a reservoir directly into the Great Kwa River. The Great Kwa River is a tributary of the Cross River Estuary, located between latitudes $4^{\circ} 45^{\prime} \mathrm{N}$ and $5^{\circ} 15^{\prime} \mathrm{N}$ and longitudes $8^{\circ} 15^{\prime} \mathrm{E}$ and $8^{\circ} 30^{\prime} \mathrm{E}$. The Great Kwa River takes its rise from the Oban Hills in Northern Cross River State, and meanders southwards through mainly the rain forest belt before discharging into the Cross River Estuary covering a distance of approximately $56 \mathrm{~km}$ with an average width of $2.8 \mathrm{~km}$ at the mouth where it empties into the Cross River Estuary. The River is home to many fish species of commercial importance, including, bonga, Ethmalosa fimbriata, Sardinella spp, Illisha Africana, Chrysichthys nigrodigitatus. Many shellfishes including prawn, Penaues notialis, Macrobrachium maacrobrachion, Macrobrachium vollenhovenii shrimp, mollusc like periwinkle, Pachymelina aurita. Therefore the fisheries in the river system contribute significantly to the economy of the people of Calabar and beyond.

Despite the potential dangers of the wastewater discharge from the University Teaching Hospital into the Great Kwa River and the importance of the River itself on the socio-economic life of the people of the area, there is no documented study on the impact of this waste water discharge on the River system. We therefore undertook the study to assess the possible impacts of the waste water discharge on the biota of the Great Kwa River. The objectives included the assessment of the impact of the waste water on the physico-chemical parameters of the water, the assessment of the distribution and abundance of the plankton species in the River system.

\section{Materials and Methods}

The study area is the Great Kwa River which takes its origin from the Oban Hills and meanders through the Westward fringes cutting across the rainforest vegetation before 
emptying its waters into the Cross River Estuary. The Great Kwa River serves as a major source of drinking water, water for agricultural, industrial and domestic uses artisanal fisheries and transportation thus the livelihood of residents in the study area is dependent to a great extent on the health and sustainability of the Great Kwa River.

Three sampling locations were selected for the study. Station 1 was Atimbo Bridge which links the Calabar Metropolis to Akpabuyo Local Government Area. This station is upstream of the River about $10 \mathrm{~km}$ away from the Teaching Hospital. Station 2 was Esuk Atu which receives the waste water discharge from the University of Calabar Teaching Hospital, while station three was Obufa Esuk Beach, downstream of the point of discharge and $5 \mathrm{~km}$ from Station 2. Water samples were collected in the month of December from the three stations. The samples were taken to the Institute of Oceanography Central Laboratory for plankton analysis using standard methods.

\section{Results and Discussion}

Table 1: Plankton distribution and abundance in the month of December 2016.

\begin{tabular}{|c|c|c|c|}
\hline Plankton Species (cells/l) & Atimbo & Esuk Atu & Obufa Esuk \\
\hline \multicolumn{4}{|l|}{ Phytoplankton } \\
\hline \multicolumn{4}{|l|}{ Bacillariophyceae } \\
\hline Aulacodiscus undulata & 2000 & 0 & 0 \\
\hline Coscinodiscus radiata & 4000 & 0 & 400 \\
\hline Cyclotella sp & 6000 & 0 & 0 \\
\hline Gyrosigma sp & 0 & 400 & 0 \\
\hline Leptocylindricus daniscus & 2,800 & 0 & 0 \\
\hline Melosira granulata & 4,000 & 2,000 & 1,200 \\
\hline Navicula petersonii & 32,000 & 114,000 & 2,400 \\
\hline Nitzschia sp & 0 & 2,000 & 0 \\
\hline Pinnularia borealis & 400 & 1600 & 0 \\
\hline Surrirella oblonga & 0 & 0 & 400 \\
\hline Surrirella ovalis & 400 & 0 & 0 \\
\hline Synedra sp & 0 & 0 & 0 \\
\hline \multicolumn{4}{|l|}{ Chlorophyceae } \\
\hline Mougeotia sp & 0 & 1200 & \\
\hline \multicolumn{4}{|l|}{ Cyanphyceae } \\
\hline Lyngbya sp & 0 & 1,600 & 0 \\
\hline Oscillatoria rubiscens & 1200 & 36,000 & 0 \\
\hline \multicolumn{4}{|l|}{ Zooplankton } \\
\hline \multicolumn{4}{|l|}{ Crustacea } \\
\hline \multicolumn{4}{|l|}{ Copepods } \\
\hline Cyclops sp & 3600 & 2,000 & 5200 \\
\hline \multicolumn{4}{|l|}{ Tintinnids } \\
\hline Tintinnids sp & 400 & 0 & 0 \\
\hline
\end{tabular}

Table 2: Physico-chemical parameters in the three study sites in the month of December 2016.

\begin{tabular}{|c|c|c|c|}
\hline Parameters & Atimbo & Esuk Atu & Obufa Esuk \\
\hline Dissolved Oxygen $(\mathrm{mg} / \mathrm{l})$ & 5 & 5.3 & 5.1 \\
\hline Turbidity $(\mathrm{NTU})$ & 437.16 & 109.28 & 327.87 \\
\hline Salinity $(\mathrm{ppt})$ & 0.02 & 0.08 & 0.02 \\
\hline $\mathrm{pH}$ & 5.68 & 5.62 & 5.66 \\
\hline Conductivity $(\mu / \mathrm{cm})$ & 37.1 & 120.5 & 32.4 \\
\hline Nitrate $(\mathrm{mg} / \mathrm{l})$ & 1.824 & 0.161 & 6.696 \\
\hline Phosphate $(\mathrm{mg} / \mathrm{l})$ & 0.034 & 0.01 & 0.28 \\
\hline Ammonium $(\mathrm{mg} / \mathrm{l})$ & 1.611 & 0.348 & 1.67 \\
\hline Temperature $\left({ }^{\circ} \mathrm{C}\right)$ & 28 & 29 & 28.5 \\
\hline
\end{tabular}

The results of plankton analyses show that there were clear differences amongst the three sampling sites. Most of the planktons identified and quantified were more abundant upstream and had a decline in their population at Esuk Atu where the waste water discharged took place. Further downstream, at Obufa Esuk such planktons showed a kind of population buildup again. (Table 1) shows the distribution and abundance of plankton in along the river at the three sampling sites, while (Table 2) shows the physico-chemical parameters of the water. Six planktons species were identified at the upstream points that were not found at the point of impact and downstream. As shown in the table, plankton species of the diatom family Aulacodiscus undulata, Coscinodiscus radiata, Cyclotella sp, Leptocylindricus danicus, Melosira granulata and Cyclops were more abundant in the upstream section of the river away from the point of impact. The difference in physic-chemical parameters between the three sites are noticed in conductivity, ammonium levels and turbidity. Such differences may also contribute to the variation in the plankton populations. Conversely, some planktons were more abundant at the impact points while they were absent at the upstream site. Four plankton species were identified at the points of impact that were absent at the upstream site.

Three plankton species had extremely higher populations at the point of waste water discharge than at the upstream. These were Navicula petersernii, Pinnularia borealis, and Oscillatoria rubiscens. The result indicates that there may be a major impact on the Great Kwa River possibly as a result of waste water discharge from the Teaching Hospital. The impact is on the biota particularly the plankton and zooplankton. Mostly affected phytoplanktons species included Coscinodiscus radiata, Gyrosigma sp. Cyclotella stegilligera, Pinnularia borealis, where the populations is higher upstream but suffers drastic decline at the point of discharge of the waste water from the University Teaching Hospital. These species may be outrightly affected by drugs like antibiotic residue that might be washed into the sewage effluent.

Kummerer [4] mentioned that it is often assumed that hospitals are the most important source for the input of 
antibiotics and resistant bacteria into municipal waste water. Untreated industrial waste such as those generated from hospitals has also rendered many aquatic environments toxic for organisms and unusable for humans; here, the pollution consists of many chemicals including antibiotics. Adewale et al. [5] in an attempt to assess of medical waste management in some hospitals in Lagos, Nigeria, found out that $25 \%$ of waste generated in hospitals is regarded as hazardous. It is possible therefore that the untreated waste water from the University of Calabar Teaching Hospital may contain antibiotics, thereby being responsible for the differences in plankton abundance and distribution along the Great Kwa River.

Planktons form the basis of aquatic food chain particularly in the marine environment. The phytoplanktons and zooplanktons identified and impacted upon in this study are major food organisms for commercially important fish species in the Great Kwa River and the entire Cross River estuary. Coscinodiscus species mostly affected in this study and Gyrosigma $s p$ were reported by Am-AD and Akpan [6,7] as the major food items recovered in the stomach of bonga fish, Ethmalosa fimbriata, which forms the most important single species fishery of the Cross River estuary and its adjacent coastal water. This report is a short communication and therefore not conclusive. However our finding points to possible alteration of plankton communities by the wastewater from the University of Calabar Teaching Hospital.

We intend to carry out a one year assessment of the impact of wastewater discharge from the Teaching Hospital on the Great
Kwa River in order to capture seasonal variation. The water from the reservoir that connects the Teaching Hospital sewage tank to the Great Kwa River needs to be analyzed for possible pharmaceuticals and other radioactive substances. The water of the Great Kwa River needs also to be analyzed for the same constituents. We therefore need support from government and International Organization to fund this project in view of the importance of the river system in the life of the riverine communities in Cross River state of Nigeria.

\section{References}

1. Emmanuel E, Blanchard JM, Keck G, Perrodin Y (2001) Caractérisation chimique, biologique et ecotoxicologique des effluents hospitalier. Dechets Science et Techniques, revue francophone d'ecologie industrielle, N 22-2eme trimester 31-33.

2. WHO (1985) Management of waste from Hospitals and other Health Care Establishments. EURO Rep Stud 97: 1-61.

3. Jackson MK, Morris GP, Smith PG, Crawford JF (1989) Environmental Health Reference Book. Butterworth- Heinemann, London, p. 480.

4. Kummerer K (2009) Antibiotics in Aquatic environment- a reviewPart II. Chemosphere 75(4): 435-441.

5. Adewale 0, Adewoye A, Oparah A (2016) Assessment of medical waste Management in Seven Hospitals in Lagos, Nigeria. BMC Public Health 16: 269.

6. Ama-AD, Akpan ER (2004) Factors influencing the emigration of juvenile bonga from the Cross River Estuary. Proceedings of $19^{\text {th }}$ Annual conference of Fisheries Society of Nigeria held. pp. 737-744.

7. Ama-AD, Akpan ER (2011) Emigration of juvenile bonga from the Cross River Estuary, Nigeria. Nigerian Journal of Fisheries 8(1).

\section{Your next submission with Juniper Publishers will reach you the below assets}

- Quality Editorial service

- Swift Peer Review

- Reprints availability

- E-prints Service

- Manuscript Podcast for convenient understanding

- Global attainment for your research

- Manuscript accessibility in different formats ( Pdf, E-pub, Full Text, Audio)

- Unceasing customer service

Track the below URL for one-step submission https://juniperpublishers.com/online-submission.php 